\title{
Development and Performance Evaluation of Light Shelves Using Width-Adjustable Reflectors
}

\author{
Heangwoo Lee $\mathbb{D},{ }^{1}$ Seonghyun Park $\mathbb{D D}^{2},{ }^{2}$ and Janghoo Seo $\mathbb{D}^{3}$ \\ ${ }^{1}$ The Graduate School of Techno Design, Kookmin University, Seoul 02707, Republic of Korea \\ ${ }^{2}$ Department of Architecture, Graduated School, Kookmin University, Seoul 02707, Republic of Korea \\ ${ }^{3}$ School of Architecture, Kookmin University, Seoul 02707, Republic of Korea \\ Correspondence should be addressed to Janghoo Seo; seojh@kookmin.ac.kr
}

Received 11 December 2017; Accepted 29 January 2018; Published 1 April 2018

Academic Editor: Geun Y. Yun

Copyright (c) 2018 Heangwoo Lee et al. This is an open access article distributed under the Creative Commons Attribution License, which permits unrestricted use, distribution, and reproduction in any medium, provided the original work is properly cited.

In recent years, there has been an increase in the consumption of energy for lighting purposes, which has led to an increase in the number of studies being conducted on this subject. Most studies have focused on light shelves, which are daylighting systems used for reducing the lighting energy required for the interiors of buildings. However, the existing light shelves cannot actively deal with external environmental factors, which often lead to an infringement of the right to light during the night when the performance of the light shelf deteriorates. Therefore, in this study, we propose a light shelf with a width-adjustable reflector and verify its validity using a testbed. The reflector of the proposed light shelf system is modularized so that the length can be adjusted in stages. The optimum width of the light shelf is calculated in terms of the energy reduction and uniformity ratio improvement, and the obtained optimum width is varied depending on the season. We find that the width-adjustable reflector can save $20 \%$ and $21.6 \%$ more lighting energy than light shelves with fixed reflector widths of $0.3 \mathrm{~m}$ and $0.6 \mathrm{~m}$, respectively.

\section{Introduction}

According to the 2010 report of the International Energy Agency (IEA), which is an international energy organization based in the United States, the consumption of lighting energy in the building sector is $18 \%$ of the total energy consumption in this sector. The lighting energy consumption in the building sector is expected to increase continuously. Therefore, an increasing number of studies are focusing on the use of light shelves to reduce the lighting energy consumption of buildings [1-5]. A light shelf is a daylighting system installed on windows, which introduces external natural light into the interiors of a building. The daylight performance of a light shelf significantly deteriorates at night and during the day when the external illumination is low. This infringes on the right to light because the light shelf blocks the external view. The possible infringement of the right because of the installation of a light shelf may be less significant when compared to awning devices, such as a louver. When the installation height of the light shelf is low, natural light is brought deeper indoors, which helps to improve the lighting performance. Studies on light shelves have shown that the most appropriate distance for a light shelf from the bottom surface in an indoor environment is $1,800 \mathrm{~mm}[6,7]$; therefore, it is necessary to consider the possibility of an infringement of the right to light when designing and installing a light shelf. In addition, an external light shelf has outstanding daylight performance [6], but it is an external projection (i.e., a device attached to the outside of a building). Thus, the light shelf can be damaged by strong winds when used in high-rise buildings [8]. In winters, the light shelf may cause [9] an increase in the consumption of heating energy by blocking incoming solar radiation from the outside. These problems can hinder the development of the light shelf industry; therefore, research is essential for solving such problems by controlling the area where natural lighting is provided using a light shelf. Hence, in this study, we propose a light shelf with a width-adjustable reflector and conduct a performance evaluation based on a full-scale testbed to verify the feasibility and effectiveness of this light shelf; we also establish the basic data for a light shelf design. 
1.1. Concept of a Light Shelf and Literature Review. A light shelf is a daylighting system that introduces external natural light into the building interiors by reflecting the light from the light shelf's reflector and the indoor ceiling surface (Figure 1). Also, a light shelf improves the problems of glare or illumination imbalance by blocking the direct introduction of external natural light into the interior space. The variables for determining the performance of a light shelf include the height, width, angle, and material of the light shelf; appropriate variable control is required to maximize the performance of the light shelf.

In Table 1, we review and summarize previous research on light shelves $[8,10-22]$. Based on these studies, we chose the angle of the light shelf as the variable to be applied for the operation of a light shelf in response to the external environment. This is because the amount and position of natural light brought into the indoor space change according to the angle of the light shelf, and it is easy to improve the lighting performance of the light shelf by observing these changes (Figure 2). In addition, the widths of the light shelves examined in previous research were fixed at a certain value for performance evaluation. Thus, a light shelf with a widthadjustable reflector was proposed in this study to distinguish it from the light shelves used in the previous studies.

1.2. Optimum Indoor Illumination Standard. In this study, a $1: 1$ scale testbed was used to evaluate the performance of the light shelf. The performance was evaluated by obtaining the lighting usage depending on the variables of the light shelf for maintaining the optimum illumination for an indoor space. An optimum indoor illumination standard was used as the index for evaluating the performance of the light shelf in this study, and the optimum indoor illumination standards suggested in the United States, Japan, and Korea were reviewed (Table 2) [23-25]. In this study, the optimum indoor illumination standard for the light shelf performance evaluation was set to $500 \mathrm{~lx}$ based on the review of the aforementioned optimum indoor illumination standards.

\section{Method}

2.1. Light Shelf with a Width-Adjustable Reflector. To design a light shelf with a width-adjustable reflector, we stacked reflectors on top of one another; a width-adjustable reflector helps to actively cope with diverse external environments (Figure 3). The width of the light shelf reflector could be adjusted in stages. A light shelf with a width-adjustable reflector can minimize the problems associated with existing light shelves having fixed reflector widths. The common problem areas are damage caused by wind pressure and the possible infringement of the right to light. Also, adjusting the width of the light shelf reflector can resolve the problem of receiving reduced solar radiation because of the shading of the light shelf during winter.

We proposed a manual system and an automated system for designing the light shelf with a width-adjustable reflector. In the automated system, the control was carried out based on the following procedures. First, at night and before an occupant entered the room, the width of the light shelf

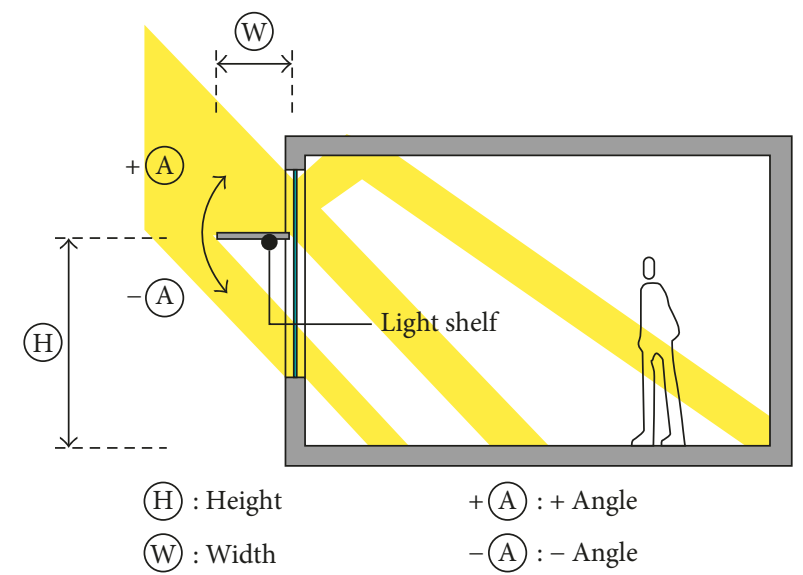

Figure 1: Concept of a variable light shelf.

reflector was maintained at its minimum; each light shelf reflector module was maintained in stacks. Minimizing the width of the light shelf reduced the possibility of an infringement of the right to light if the light shelf was unable to function. Maintaining a minimum width also helps to reduce the damage caused by external environmental factors such as wind pressure. Second, when an occupant entered the room, the angle of the light shelf was controlled and its width was maintained at the minimum length. When the illumination sensors directly linked with the lighting detected an illumination of $500 \mathrm{~lx}$ during the angle control, the light shelf control was stopped. However, when the illumination sensors linked with the indoor lighting detected an illumination less than $500 \mathrm{~lx}$ despite the angle control, the width of the light shelf reflector was controlled. Third, the width of the light shelf was increased in stages, and the angle was controlled at each stage. We controlled the angle so that the illumination sensors linked with the indoor lighting could detect an illumination of $500 \mathrm{~lx}$ through a repeated control process. When the illumination sensors could not detect $500 \mathrm{~lx}$ despite repeating the control process, reoperation and lighting control were performed so that the length and angle could be adjusted to obtain a value close to $500 \mathrm{~lx}$.

2.2. Performance Evaluation Environment Setting. In this study, a testbed was established for evaluating the performance of the light shelf using a width-adjustable reflector; the testbed had a width of $4.9 \mathrm{~m}$, a depth of $6.6 \mathrm{~m}$, and a height of $2.5 \mathrm{~m}$, as shown in Table 3 . The window where the light shelf was installed had a width of $2.2 \mathrm{~m}$ and a height of $1.8 \mathrm{~m}$. The glass used for the window was a pair glass with $80 \%$ transmissivity. In addition, an artificial climate chamber equipped with an artificial sunlight radiation device was installed for the external environment of the testbed. Using the artificial sunlight radiation device, we could produce an external light environment for each season by adjusting the amount of light, height, and angle of the light source. The sunlight radiation device used in this study was an artificial light source, which may be slightly different from the actual light source. However, the artificial light source was effective; it had an A grade in terms of illuminance uniformity 
TABLE 1: Details of previous studies on light shelves.

\begin{tabular}{|c|c|c|c|}
\hline \multirow{2}{*}{ Title of study } & \multirow{2}{*}{ Year } & \multicolumn{2}{|c|}{ Light shelf variables } \\
\hline & & Width & Width adjustability \\
\hline Effectiveness of a perforated light shelf for energy saving [8] & 2017 & Fixed at a certain value & Not considered \\
\hline Performance evaluation of light shelves [10] & 2017 & Fixed at a certain value & Not considered \\
\hline $\begin{array}{l}\text { Daylighting performance improvement of a light shelf using diffused } \\
\text { reflection [11] }\end{array}$ & 2017 & Fixed at a certain value & Not considered \\
\hline $\begin{array}{l}\text { Study on movable light shelf system with location-awareness } \\
\text { technology for lighting energy saving [12] }\end{array}$ & 2017 & Fixed at a certain value & Not considered \\
\hline $\begin{array}{l}\text { Investigating the influence of light shelf geometry parameters on } \\
\text { daylight performance and visual comfort, a case study of educational } \\
\text { space in Tehran, Iran [13] }\end{array}$ & 2016 & Fixed at a certain value & Not considered \\
\hline $\begin{array}{l}\text { Evaluating daylight performance of light shelves combined with } \\
\text { external blinds in south-facing classrooms in Athens, Greece [14] }\end{array}$ & 2016 & Fixed at a certain value & Not considered \\
\hline $\begin{array}{l}\text { Dynamic internal light shelf for tropical daylighting in high-rise office } \\
\text { buildings [15] }\end{array}$ & 2016 & Fixed at a certain value & Not considered \\
\hline $\begin{array}{l}\text { The effects of direct sunlight on light shelf performance under tropical } \\
\text { sky [16] }\end{array}$ & 2015 & Fixed at a certain value & Not considered \\
\hline $\begin{array}{l}\text { New static light shelf system design of clerestory windows for Hong } \\
\text { Kong [17] }\end{array}$ & 2014 & Fixed at a certain value & Not considered \\
\hline $\begin{array}{l}\text { Maximizing the light shelf performance through interaction between } \\
\text { light shelf geometries and a curved ceiling [18] }\end{array}$ & 2010 & Fixed at a certain value & Not considered \\
\hline $\begin{array}{l}\text { Optimizing performance of the light shelf by modifying ceiling } \\
\text { geometry in highly luminous climates [19] }\end{array}$ & 2008 & Fixed at a certain value & Not considered \\
\hline $\begin{array}{l}\text { Indoor daylight climate-influence of light shelf and model reflectance } \\
\text { on light shelf performance in Madrid for hours with unit sunshine } \\
\text { fraction [20] }\end{array}$ & 2002 & Fixed at a certain value & Not considered \\
\hline Advanced optical daylighting systems: light shelves and light pipes [21] & 1997 & Fixed at a certain value & Not considered \\
\hline The development of coefficients of utilization for light shelves [22] & 1993 & Fixed at a certain value & Not considered \\
\hline
\end{tabular}

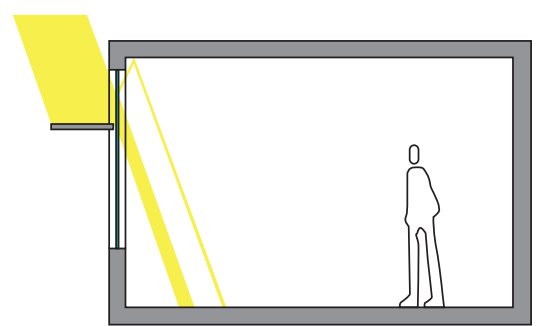

(a)

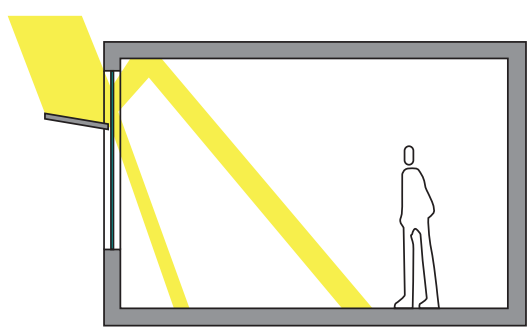

(b)

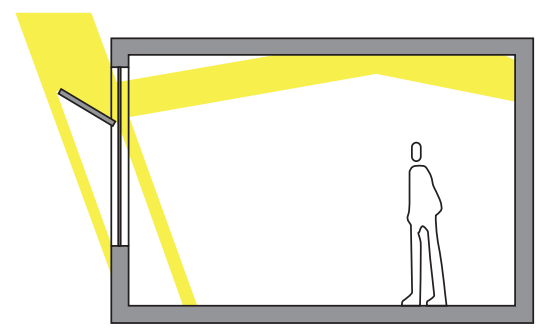

(c)

Figure 2: Inflow of light corresponding to three angles of the light shelf. (a) Light shelf angle: $0^{\circ}$, (b) light shelf angle: $10^{\circ}$, and (c) light shelf angle: $30^{\circ}$.

TABLE 2: Recommended illumination levels.

\begin{tabular}{lcccc}
\hline Task grade & Recommended levels of illumination & $\begin{array}{c}\text { Minimum allowed } \\
\text { illumination (lx) }\end{array}$ & $\begin{array}{c}\text { Standard allowed } \\
\text { illumination (lx) }\end{array}$ & $\begin{array}{c}\text { Maximum allowed } \\
\text { illumination (lx) }\end{array}$ \\
\hline \multirow{2}{*}{ General } & IES (USA) & $\mathbf{5 0 0}$ & 750 & $\mathbf{5 0 0}$ \\
& JIS Z 9110 (Japan) & 300 & 400 & 750 \\
\hline \multirow{3}{*}{ Simple } & KS A 3011 (Republic of Korea) & 300 & 300 & 600 \\
& IES (USA) & 200 & 200 & $\mathbf{5 0 0}$ \\
& JIS Z 9110 (Japan) & 150 & 200 & 300 \\
\hline
\end{tabular}

according to the ASTM E927-85 standards. Using the artificial light source, we could establish the same external light environments for different performance evaluations. Indoor lighting was installed at four locations following the four point method of IES [23]. For each lighting, we used LEDtype lighting that is capable of eight-stage dimming control.

For the performance evaluation of this study, 10 illumination sensors were arranged (Figure 4) to measure the 

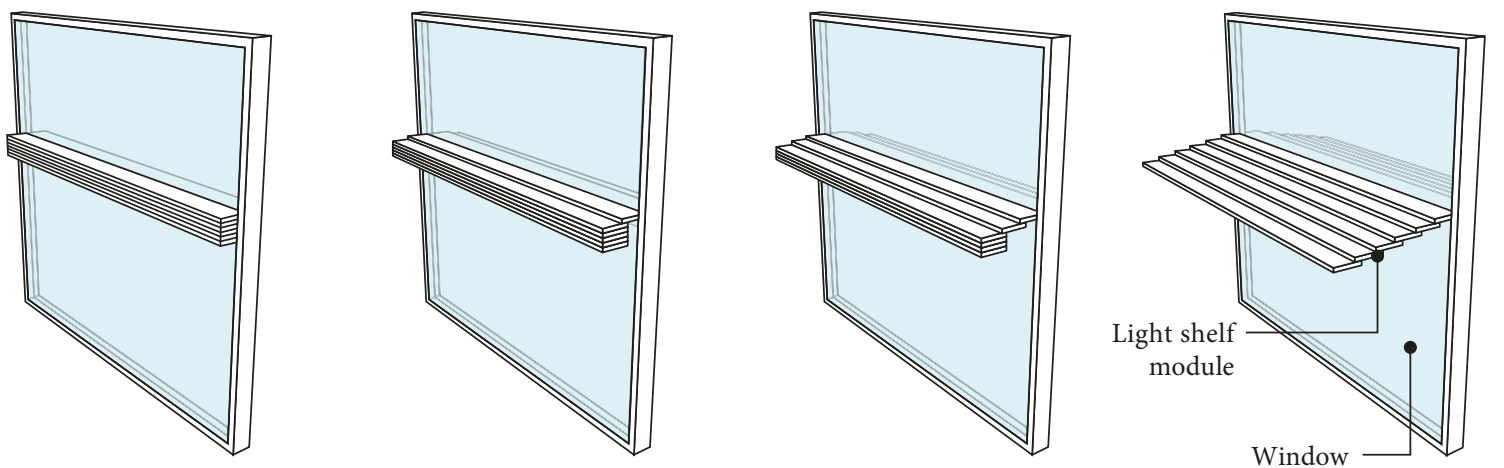

(a)
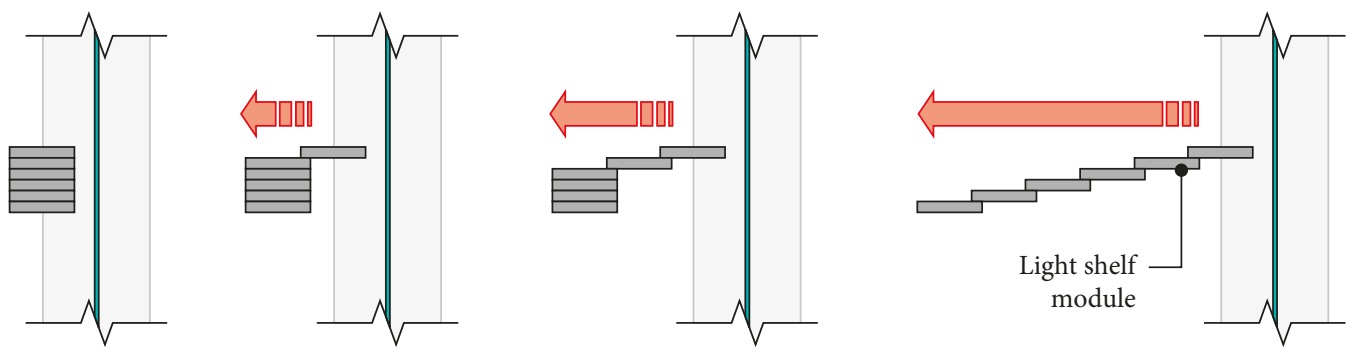

(b)

Figure 3: Schematic of a light shelf with a width-adjustable reflector. (a) Adjustment of the width of the light shelf at the minimum and maximum lengths (stages 1, 2, 3, and 6). (b) Width adjustment for each light shelf stage (stages 1, 2, 3, and 6).

TABLE 3: Setting of testbed.

Room size, material

Window size, material

Lighting

Illuminance sensor

External illuminance

Solar altitude

Direction (culmination time)

Energy consumption monitoring system (i) $4.9 \mathrm{~m}(W) \times 6.6 \mathrm{~m}(D), 2.5 \mathrm{~m}$ (ceiling height)

(ii) Ceiling: reflexibility $86 \%$, wall: reflexibility $46 \%$, floor: reflexibility $25 \%$

(i) $2.2 \mathrm{~m}(W) \times 1.8 \mathrm{~m}(H)$

(ii) $12 \mathrm{~mm}$ pair glass $(3 \mathrm{CL}+6 \mathrm{~A}+3 \mathrm{CL})$

(iii) Transmissivity: $80 \%$

(i) 8 level dimming (LED type) 4 locations

(ii) Dimension (mm): $600 \times 600$

(iii) Dimming range: $10-100 \%$

(iv) Electricity consumption based on the level of dimming lighting control: lv $1(12 \mathrm{~W})$,

lv $2(18 \mathrm{~W})$, lv $3(22 \mathrm{~W})$, lv $4(28 \mathrm{~W})$, lv $5(34 \mathrm{~W})$, lv 6 (39 W), lv $7(43 \mathrm{~W})$, lv 8 (51 W)

(i) Sensing element: silicon photo sensor with filter

(ii) Detection range: $0-200,000 \mathrm{~lx}$

(iii) Precision: $\pm 3 \%$

Winter: 30,000 lx, middle season: 60,000 lx, summer: 80,000 lx

Winter: $23.5^{\circ}$, middle season: $52.5^{\circ}$, summer: $76.5^{\circ}$

South (south-central time)

(i) Model: SPM-141

(ii) Measurement capacity: single phase

(iii) Margin of error: within $2.0 \%$

Overview of the testbed and artificial sunlight source

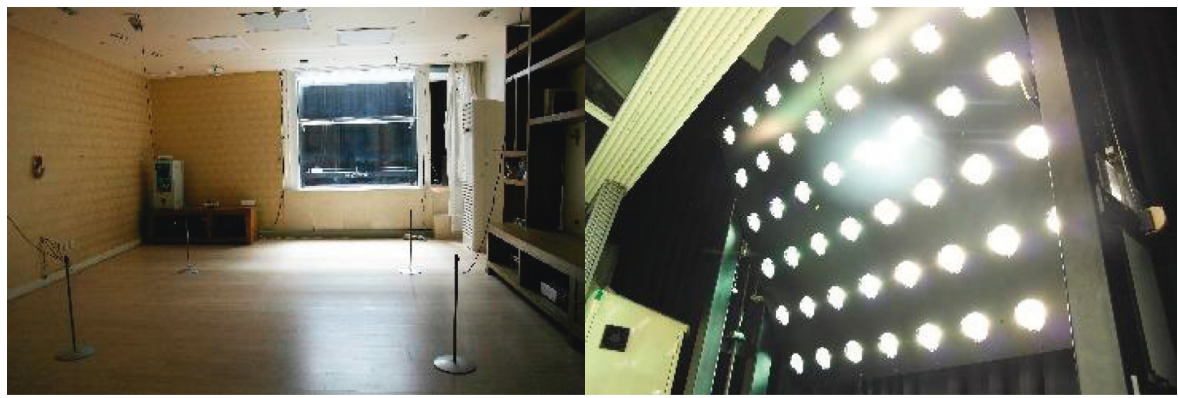



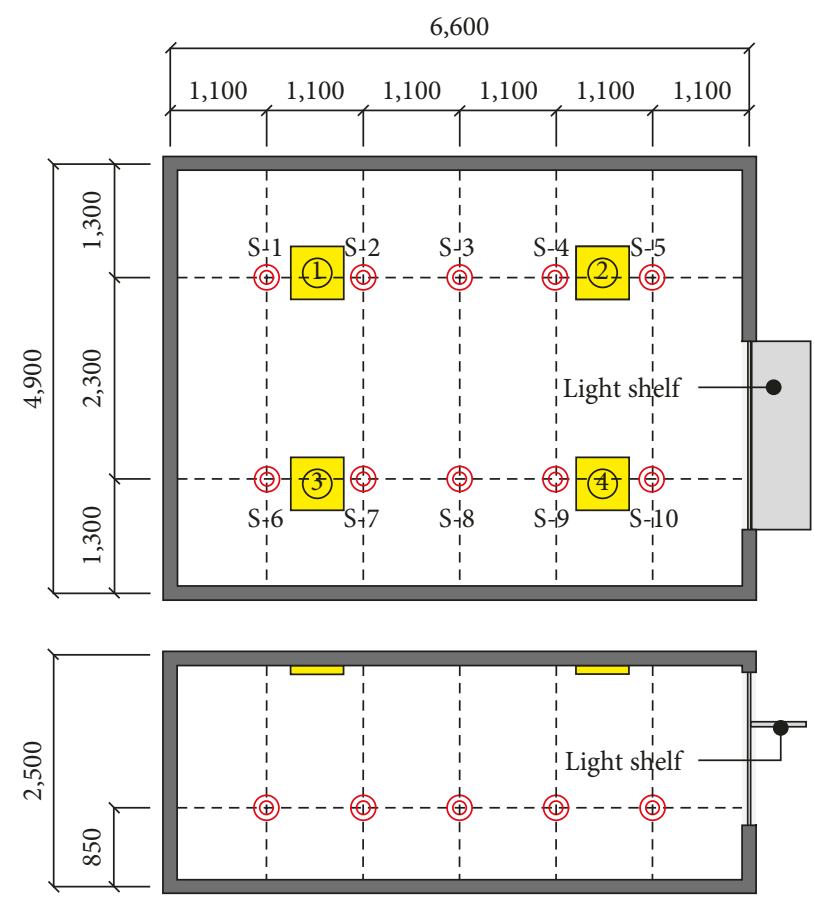

() Illuminance sensor

$\square$ Lighting

Figure 4: Plan and section of testbed and the location of the illumination sensor.

TABLE 4: Three cases for evaluating light shelf performance.

\begin{tabular}{lcc}
\hline & \multicolumn{2}{c}{ Control of light shelf variables } \\
& Angle control & Width control \\
\hline Case 1 & & $0.3 \mathrm{~m}$ fixed \\
Case 2 & $-10^{\circ}, 0^{\circ}, 10^{\circ}$, & $0.6 \mathrm{~m}$ fixed \\
Case 3 & $20^{\circ}, 30^{\circ}$ & $0.1 \mathrm{~m}-0.6 \mathrm{~m}$ (width is adjustable \\
& & in stages at intervals of $0.1 \mathrm{~m}$ ) \\
\hline
\end{tabular}

indoor illumination distribution depending on the installation of the light shelf. The illumination sensor was installed at $1.1 \mathrm{~m}$ intervals based on the size of the space. The height of the illumination sensor was $850 \mathrm{~mm}$ from the floor to the working surface.

2.3. Performance Evaluation Method. To evaluate the performance of a light shelf fitted with a width-adjustable reflector, we first verified the validity of the light shelf having a widthadjustable reflector-we called this "Case 3." For performance evaluation, the widths of the fixed light shelf were set as $0.3 \mathrm{~m}$ and $0.6 \mathrm{~m}$; these values were determined based on previous studies related to light shelves $[6,26-30]$. The lighting energy consumption and uniformity ratio of Case 3 were calculated and compared with those of the light shelves with fixed reflector widths of $0.3 \mathrm{~m}$ ("Case 1") and $0.6 \mathrm{~m}$ ("Case 2"); the results are presented in Table 4 . The reflector width for Case 3 could be adjusted in six stages at $0.1 \mathrm{~m}$ intervals (from $0.1 \mathrm{~m}$ to $0.6 \mathrm{~m}$ ), as shown in Figure 5. In addition, the type of light shelf proposed in this study was an outdoor type light shelf, which was set according to the standards of an outdoor type of light shelf. A profile with a size of $20 \mathrm{~mm} \times 20 \mathrm{~mm}$ was used to manufacture the light shelf with a width-adjustable reflector. Second, to calculate the lighting electricity consumption depending on the variables of the light shelf, the illumination sensors 2, 4, 7, and 9 were linked with the lightings 1, 2, 3, and 4, respectively. If a measured illumination value was less than $500 \mathrm{~lx}$ for the illumination sensors 2, 4, 7, and 9, dimming lighting control was carried out in sequence from the lighting that was linked with the illumination sensor having the lowest illumination value. The lighting control was stopped when $500 \mathrm{~lx}$ was reached during the dimming lighting control. The lighting energy consumption at the end was calculated and used as the index for performance evaluation. In this study, the lighting energy consumption values were calculated for summer, middle season, and winter based on a one-hour period and in the southern direction. In addition, it was necessary to allow a certain time to carry out the generalized performance evaluation of the light shelf. However, because of the mechanical characteristics of the artificial sunlight radiation device, performance evaluation was carried out only for the southern direction in this study. Therefore, a one-hour period was applied for performance evaluation. Third, the uniformity ratio of illumination was deduced in this study based on the values of illumination sensor number 1-number 10 , which were measured for each case. The variables for the light shelf and uniformity ratio of illumination were calculated as the ratio of minimum illumination to the average illumination. Fourth, to conduct the performance evaluation depending on the variables of the light shelf, the optimum 


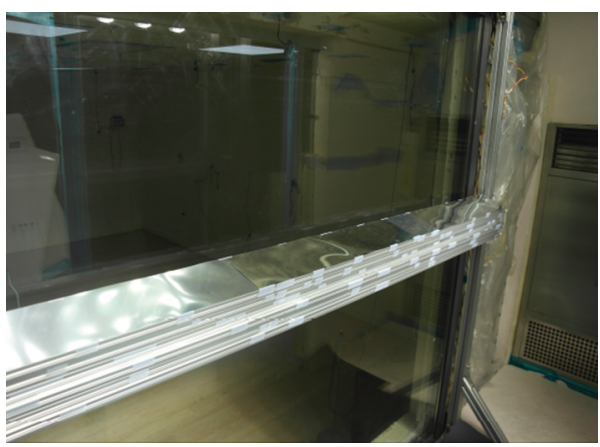

(a)

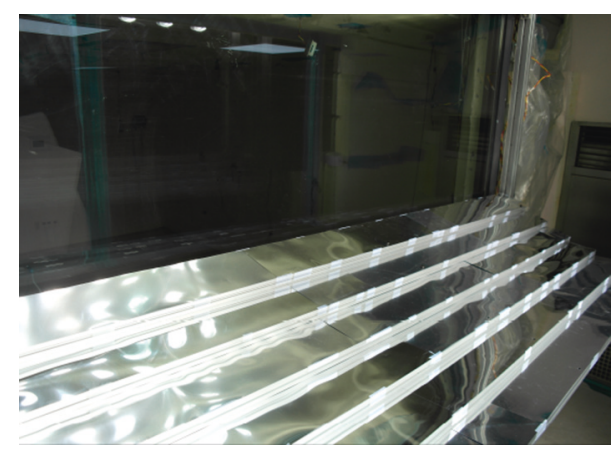

(b)

FIGURE 5: Testbed for a light shelf with a width-adjustable reflector.

TABLE 5: Setting of light shelf variables for performance evaluation.

\begin{tabular}{ll}
\hline Height & $1800 \mathrm{~mm}$ \\
Angle range & $-10^{\circ}, 0^{\circ}, 10^{\circ}, 20^{\circ}, 30^{\circ}$ \\
Reflectivity & Specular reflection film (reflexibility 85\%) \\
Type & Exterior type \\
\hline
\end{tabular}

width and optimum angle of the light shelf were calculated based on the season. We selected the optimum width and optimum angle values for the lowest lighting electricity consumption. However, when the lighting energy consumptions were identical, we selected the value with a higher uniformity ratio. Fifth, we specified the light shelf variables for the performance evaluation, as shown in Table 5 .

\section{Results and Discussion}

3.1. Performance Evaluation Result. In this study, we proposed a light shelf with a width-adjustable reflector (Case 3). To verify the validity of the suggested light shelf, its lighting energy reduction performance and uniformity ratio were calculated. We compared these results with Case 1 ( $0.3 \mathrm{~m}$ reflector) and Case 2 (0.6 $\mathrm{m}$ reflector). The following results were obtained.

First, the optimum width of the light shelf varied depending on the season, as shown in Table 6. For summer, the lighting electricity consumption values for maintaining the value of the illumination sensor linked with the indoor lighting at $500 \mathrm{~lx}$ were 0.120 and $0.114 \mathrm{kWh}$ for Case 1 and Case 2, respectively. Also, in middle season, the lighting energy consumption values for Case 1 and Case 2 were 0.102 and $0.114 \mathrm{kWh}$, respectively.

Second, the optimum angle for Case 1 and Case 2 based on the electricity consumption and uniformity ratio was $30^{\circ}$ for summer, middle season, and winter (Table 7). Based on the optimum angle, the lighting electricity consumption values for Case 1 and Case 2 were 0.285 and $0.291 \mathrm{kWh}$, respectively, for summer, middle season, and winter.

Third, for the uniformity ratio, the light shelf in Case 1 showed a higher value than that in Case 2, regardless of the season.

Fourth, for Case 3, the obtained optimum widths were $0.6 \mathrm{~m}, 0.2 \mathrm{~m}$, and $0.1 \mathrm{~m}$ for summer, middle season, and winter, respectively (Table 8). As mentioned earlier, the selection of the optimum length of the light shelf for each season was based on the lowest lighting energy consumption. In particular, Figure 6 represents the introduction of external natural light into the interior space using the light shelf. An increase in the width of the light shelf during winter decreased the amount of natural light that was directly introduced into the interior space. Also, a decrease in the width of the light shelf reflector helped reduce the lighting energy because the solar altitude is low in winter. For Case 3, the lighting electricity consumption obtained by controlling the angle of the light shelf based on the optimum width of the light shelf was $0.228 \mathrm{kWh}$. To conserve space, we present only the results for the reflector widths with the lowest electricity consumption for each season.

3.2. Discussion. In this study, the lighting electricity consumption and uniformity ratio were calculated depending on the width of the light shelf. We found that the obtained optimum width of the light shelf varied based on the lighting energy reduction and uniformity ratio, which depended on the season. This result verified Case 3, which used a light shelf with a width-adjustable reflector. Case 3 could save $20 \%$ and $21.6 \%$ more lighting energy as compared to Case 1 (using $0.3 \mathrm{~m}$ reflector) and Case 2 (using $0.6 \mathrm{~m}$ reflector), respectively (Figure 7). It seems much possible to save lighting energy in an efficient manner in Case 3 by adjusting the light shelf width in response to external light environments. This will also resolve the possible infringement of the right to light caused by previous types of fixed-width light shelves attached to skylights. Especially, previous types of light shelves tended to increase lighting energy consumption during winter because even though natural light can be brought deep into the indoors because of low solar altitude during winter, the light shelf actually interrupts or blocks natural light. However, when the light shelf width is adjustable, as suggested in this study, it minimizes the reflective area of the light shelf during winter and increases the amount of light brought from the outside; therefore, Case 3 can save $80.9 \%$ more lighting energy as compared to Case 1 and Case 2. Also, Case 3 minimizes the reflective area during winter and is advantageous in saving heating energy by securing solar radiation; therefore, it is 
TABLe 6: Performance evaluation results for light shelves with reflector widths of $0.3 \mathrm{~m}$ and $0.6 \mathrm{~m}$.

\begin{tabular}{|c|c|c|c|c|c|c|c|}
\hline \multirow{2}{*}{ Seasons } & \multicolumn{2}{|c|}{ Light shelf } & \multicolumn{2}{|c|}{ Illumination sensor (lx) } & \multirow{2}{*}{$\begin{array}{l}\text { Uniformity } \\
\text { ratio }\end{array}$} & \multirow{2}{*}{$\begin{array}{l}\text { Lighting dimming } \\
\text { control: lighting number } \\
\text { (dimming level) }\end{array}$} & \multirow{2}{*}{$\begin{array}{c}\text { Electricity } \\
\text { consumption } \\
(\mathrm{kWh})\end{array}$} \\
\hline & Width (m) & Angle & Minimum & Average & & & \\
\hline \multirow{10}{*}{ Summer } & \multirow{5}{*}{0.3} & $-10^{\circ}$ & 71.7 & 222.3 & 0.322 & $1(8) \rightarrow 3(8) \rightarrow 2(3)$ & 0.124 \\
\hline & & $0^{\circ}$ & 76.1 & 236.5 & 0.322 & $1(8) \rightarrow 3(8) \rightarrow 2(3)$ & 0.124 \\
\hline & & $10^{\circ}$ & 79.1 & 243.8 & 0.324 & $1(8) \rightarrow 3(8) \rightarrow 2(2)$ & 0.120 \\
\hline & & $20^{\circ}$ & 86.3 & 246.2 & 0.350 & $1(8) \rightarrow 3(8) \rightarrow 2(2)$ & 0.120 \\
\hline & & $30^{\circ}$ & 88.4 & 250.8 & 0.352 & $1(8) \rightarrow 3(8) \rightarrow 2(2)$ & 0.120 \\
\hline & \multirow{5}{*}{0.6} & $-10^{\circ}$ & 72.9 & 241.5 & 0.302 & $1(8) \rightarrow 3(8) \rightarrow 2(2)$ & 0.120 \\
\hline & & $0^{\circ}$ & 76.1 & 260.1 & 0.293 & $1(8) \rightarrow 3(8) \rightarrow 2(2)$ & 0.120 \\
\hline & & $10^{\circ}$ & 78.8 & 271.7 & 0.290 & $1(8) \rightarrow 3(8) \rightarrow 2(2)$ & 0.120 \\
\hline & & $20^{\circ}$ & 96.3 & 289.2 & 0.333 & $1(8) \rightarrow 3(8) \rightarrow 2(1)$ & 0.114 \\
\hline & & $30^{\circ}$ & 101.9 & 299.0 & 0.341 & $1(8) \rightarrow 3(8) \rightarrow 2(1)$ & 0.114 \\
\hline \multirow{10}{*}{ Middle season } & \multirow{5}{*}{0.3} & $-10^{\circ}$ & 81.9 & 286.1 & 0.286 & $1(8) \rightarrow 3(8) \rightarrow 2(2)$ & 0.120 \\
\hline & & $0^{\circ}$ & 86.6 & 295.6 & 0.293 & $1(8) \rightarrow 3(8) \rightarrow 2(1)$ & 0.114 \\
\hline & & $10^{\circ}$ & 91.0 & 299.0 & 0.304 & $1(8) \rightarrow 3(8) \rightarrow 2(1)$ & 0.114 \\
\hline & & $20^{\circ}$ & 99.3 & 308.6 & 0.322 & $1(8) \rightarrow 3$ & 0.102 \\
\hline & & $30^{\circ}$ & 107.4 & 310.3 & 0.346 & $1(8) \rightarrow 3(8)$ & 0.102 \\
\hline & \multirow{5}{*}{0.6} & $-10^{\circ}$ & 70.8 & 276.8 & 0.256 & $1(8) \rightarrow 3(8) \rightarrow 2(2)$ & 0.120 \\
\hline & & $0^{\circ}$ & 77.2 & 295.7 & 0.261 & $1(8) \rightarrow 3(8) \rightarrow 2(1)$ & 0.114 \\
\hline & & $10^{\circ}$ & 85.9 & 307.3 & 0.280 & $1(8) \rightarrow 3(8) \rightarrow 2(1)$ & 0.114 \\
\hline & & $20^{\circ}$ & 92.3 & 315.2 & 0.293 & $1(8) \rightarrow 3(8) \rightarrow 2(1)$ & 0.114 \\
\hline & & $30^{\circ}$ & 94.4 & 310.5 & 0.304 & $1(8) \rightarrow 3(8) \rightarrow 2(1)$ & 0.114 \\
\hline \multirow{10}{*}{ Winter } & \multirow{5}{*}{0.3} & $-10^{\circ}$ & 157.3 & 558.9 & 0.281 & $1(8) \rightarrow 3(1)$ & 0.063 \\
\hline & & $0^{\circ}$ & 160.7 & 581.8 & 0.276 & $1(8) \rightarrow 3(1)$ & 0.063 \\
\hline & & $10^{\circ}$ & 164.1 & 595.4 & 0.276 & $1(8) \rightarrow 3(1)$ & 0.063 \\
\hline & & $20^{\circ}$ & 166.2 & 601.7 & 0.276 & $1(8) \rightarrow 3(1)$ & 0.063 \\
\hline & & $30^{\circ}$ & 180.1 & 593.6 & 0.303 & $1(8) \rightarrow 3(1)$ & 0.063 \\
\hline & \multirow{5}{*}{0.6} & $-10^{\circ}$ & 139.8 & 532.4 & 0.263 & $1(8) \rightarrow 3(1)$ & 0.063 \\
\hline & & $0^{\circ}$ & 145.1 & 556.3 & 0.261 & $1(8) \rightarrow 3(1)$ & 0.063 \\
\hline & & $10^{\circ}$ & 150.5 & 582.6 & 0.258 & $1(8) \rightarrow 3(1)$ & 0.063 \\
\hline & & $20^{\circ}$ & 156.7 & 607.5 & 0.258 & $1(8) \rightarrow 3(1)$ & 0.063 \\
\hline & & $30^{\circ}$ & 164.4 & 616.7 & 0.267 & $1(8) \rightarrow 3(1)$ & 0.063 \\
\hline
\end{tabular}

TABle 7: Optimum angle and total electricity consumption for the light shelves with reflector widths of $0.3 \mathrm{~m}$ and $0.6 \mathrm{~m}$.

\begin{tabular}{|c|c|c|c|c|c|c|c|}
\hline \multirow{2}{*}{$\begin{array}{l}\text { Width } \\
(\mathrm{m})\end{array}$} & \multicolumn{2}{|r|}{ Summer } & \multicolumn{2}{|c|}{ Middle season } & \multicolumn{2}{|r|}{ Winter } & \multirow[b]{2}{*}{$\begin{array}{c}\text { Electricity } \\
\text { consumption (kWh) }\end{array}$} \\
\hline & $\begin{array}{l}\text { Optimum } \\
\text { angle }\end{array}$ & $\begin{array}{c}\text { Electricity } \\
\text { consumption (kWh) }\end{array}$ & $\begin{array}{l}\text { Optimum } \\
\text { angle }\end{array}$ & $\begin{array}{c}\text { Electricity } \\
\text { consumption (kWh) }\end{array}$ & $\begin{array}{l}\text { Optimum } \\
\text { angle }\end{array}$ & $\begin{array}{c}\text { Electricity } \\
\text { consumption (kWh) }\end{array}$ & \\
\hline 0.3 & $30^{\circ}$ & 0.120 & $30^{\circ}$ & 0.102 & $30^{\circ}$ & 0.063 & 0.285 \\
\hline 0.6 & $30^{\circ}$ & 0.114 & $30^{\circ}$ & 0.114 & $30^{\circ}$ & 0.063 & 0.291 \\
\hline
\end{tabular}

considered an advanced form of light shelf compared to previous light shelves.

In this study, we evaluated the performance of different kinds of light shelves by focusing on the reduction in energy consumption by using a light shelf with a width-adjustable reflector. The adjustment of the light shelf width helps reduce the damage caused by the weather and minimizes the possibility of an infringement of the right to light. However, this study has its limitations. The performance of the light shelf was evaluation in an artificial environment and under specific conditions, which might be different from real-life situations. Also, the economic and technical factors involved in adjusting the width of the light shelf were not considered. Further studies are required to examine these areas. In particular, this study includes the mechanism used with previous light shelves to control the angle and width. Further studies are required to evaluate the technical aspects for improving the implementation of such mechanism. Additional studies are also required to evaluate the economic performance of the proposed light shelf.

\section{Conclusion}

In this study, a light shelf with a width-adjustable reflector was proposed for efficient control and daylight performance improvement in response to changes in the external environment. To verify the validity, the performance was evaluated based on a testbed.

For the light shelf with a width-adjustable reflector proposed in this study, the reflector was modularized so that its length could be adjusted. In particular, the light shelf with a width-adjustable reflector can actively respond to the external 
TABLE 8: Performance evaluation results for a light shelf with a width-adjustable reflector.

\begin{tabular}{|c|c|c|c|c|c|c|c|}
\hline \multirow[b]{2}{*}{ Season } & \multicolumn{2}{|c|}{ Light shelf } & \multicolumn{2}{|c|}{ Illumination sensor (lx) } & \multirow[b]{2}{*}{$\begin{array}{l}\text { Uniformity } \\
\text { ratio }\end{array}$} & \multirow{2}{*}{$\begin{array}{l}\text { Lighting dimming } \\
\text { control: lighting number } \\
\text { (dimming level) }\end{array}$} & \multirow{2}{*}{$\begin{array}{c}\text { Electricity } \\
\text { consumption } \\
(\mathrm{kWh})\end{array}$} \\
\hline & $\begin{array}{l}\text { Optimum } \\
\text { width (m) }\end{array}$ & Angle & Minimum & Average & & & \\
\hline \multirow{5}{*}{ Summer } & \multirow{5}{*}{0.6} & $-10^{\circ}$ & 72.1 & 230.7 & 0.312 & $1(8) \rightarrow 3(8) \rightarrow 2(2)$ & 0.124 \\
\hline & & $0^{\circ}$ & 76.1 & 243.8 & 0.312 & $1(8) \rightarrow 3(8) \rightarrow 2(2)$ & 0.124 \\
\hline & & $10^{\circ}$ & 83.3 & 259.8 & 0.321 & $1(8) \rightarrow 3(8) \rightarrow 2(2)$ & 0.124 \\
\hline & & $20^{\circ}$ & 89.1 & 276.1 & 0.323 & $1(8) \rightarrow 3(8) \rightarrow 2(1)$ & 0.114 \\
\hline & & $30^{\circ}$ & 96.0 & 281.9 & 0.341 & $1(8) \rightarrow 3(8) \rightarrow 2(1)$ & 0.114 \\
\hline \multirow{5}{*}{$\begin{array}{l}\text { Middle } \\
\text { season }\end{array}$} & \multirow{5}{*}{0.2} & $-10^{\circ}$ & 88.8 & 280.6 & 0.316 & $1(8) \rightarrow 3(8) \rightarrow 2(2)$ & 0.124 \\
\hline & & $0^{\circ}$ & 90.2 & 286.3 & 0.315 & $1(8) \rightarrow 3(8) \rightarrow 2(2)$ & 0.124 \\
\hline & & $10^{\circ}$ & 92.9 & 293.5 & 0.316 & $1(8) \rightarrow 3(8) \rightarrow 2(1)$ & 0.114 \\
\hline & & $20^{\circ}$ & 93.8 & 296.0 & 0.317 & $1(8) \rightarrow 3(8) \rightarrow 2(1)$ & 0.114 \\
\hline & & $30^{\circ}$ & 98.0 & 299.9 & 0.327 & $1(8) \rightarrow 3(8)$ & 0.102 \\
\hline \multirow{6}{*}{ Winter } & \multirow{6}{*}{0.1} & $-10^{\circ}$ & 177.2 & 625.55 & 0.283 & $1(8) \rightarrow 3(2)$ & 0.069 \\
\hline & & $0^{\circ}$ & 177.6 & 640.24 & 0.277 & $1(8) \rightarrow 3(2)$ & 0.069 \\
\hline & & $10^{\circ}$ & 182.4 & 656.49 & 0.278 & $1(8)$ & 0.012 \\
\hline & & $20^{\circ}$ & 189.2 & 677.52 & 0.279 & $1(8)$ & 0.012 \\
\hline & & $30^{\circ}$ & 194.3 & 672.78 & 0.289 & $1(8)$ & 0.012 \\
\hline & & & & & \multicolumn{2}{|c|}{ Total electricity consumption (kWh): } & 0.228 \\
\hline
\end{tabular}

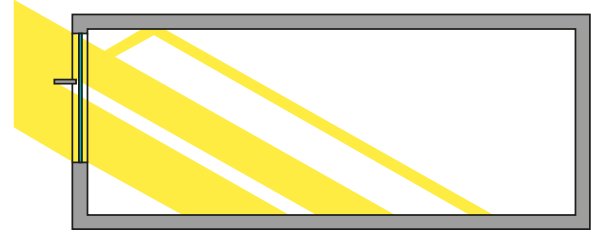

(a)

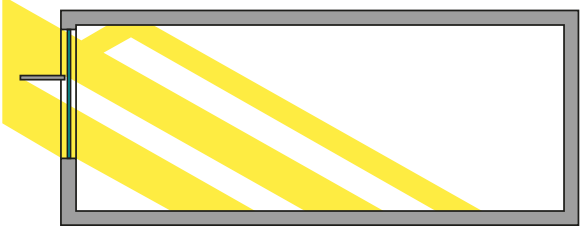

(b)

FIGURE 6: Introduction of light depending on the width of the light shelf for winter. (a) Light shelf with a $0.3 \mathrm{~m}$ width. (b) Light shelf with a $0.6 \mathrm{~m}$ width.

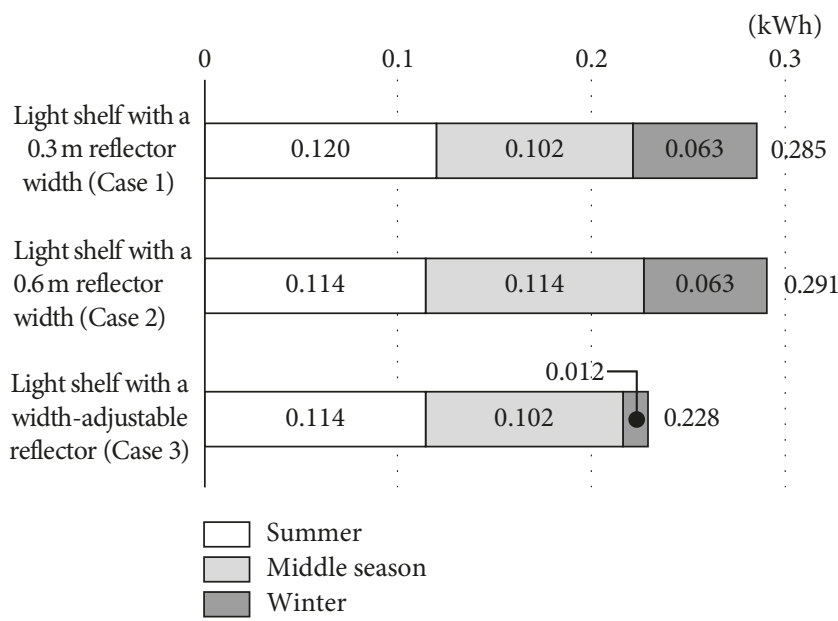

Figure 7: Lighting electricity consumption for Case 1, Case 2, and Case 3.

environmental changes by minimizing the width when the efficiency of the light shelf decreases (e.g., at night); this can reduce the problems associated with the existing light shelves. The optimum width of the light shelf varied with the lighting energy reduction and uniformity ratio depending on the season. This was resolved by adjusting the width of the reflector.
We found that Case 3 (proposed in this study) could save $20 \%$ and $21.6 \%$ more lighting energy as compared to Case 1 and Case 2, respectively. In particular, Case 3 minimized the reflective area of the light shelf during winter, and could save $80.9 \%$ more lighting energy as compared to Case 1 and Case 2. 
In this study, we helped resolve the problems associated with existing light shelves, and lighting energy could be saved by improving the daylight performance. This study has its limitations. The economic and technical examinations for controlling the light shelf width were not considered, and the study was conducted in an artificial environment. Future studies need to address these limitations and resolve related energy issues in the building sector.

\section{Conflicts of Interest}

The authors declare that they have no conflicts of interest.

\section{Acknowledgments}

This work was supported by the National Research Foundation of Korea (NRF) grant funded by the Korean government (NRF-2015R1C1A1A01052784).

\section{References}

[1] A. D. Galasiu, G. R. Newsham, C. Suvagau, and D. M. Sander, "Energy saving lighting control systems for open-plan offices: a field study," Leukos, vol. 4, no. 1, pp. 7-29, 2007.

[2] D. K. Tiller, X. Guo, G. P. Henze, and C. E. Waters, "The application of sensor networks to lighting control," Leukos, vol. 5, no. 4, pp. 313-325, 2009.

[3] X. Guo, D. K. Tiller, G. P. Henze, and C. E. Waters, "Analytical methods for application to sensor networks for lighting control," Leukos, vol. 5, no. 4, pp. 297-311, 2009.

[4] G. Lowry, "Energy saving claims for lighting controls in commercial buildings," Energy and Buildings, vol. 133, pp. 489-497, 2016.

[5] L. Xu, Y. Pan, Y. Yao, D. Cai, Z. Huang, and N. Linder, "Lighting energy efficiency in offices under different control strategies," Energy and Buildings, vol. 138, pp. 127-139, 2017.

[6] H. W. Lee, D. S. Kim, and Y. S. Kim, "Simulation study on the performance evaluation of light shelf focused on the depth of space and the dimensions and angles of light shelf," Journal of the Architectural Institute of Korea Planning \& Design, vol. 29, no. 3, pp. 335-344, 2013.

[7] G. Yun, D. W. Sho, and K. S. Kim, "A study on visual environment evaluation of residential space using the radiance program," Journal of the Architectural Institute of Korea Planning \& Design, vol. 27, no. 2, pp. 227-234, 2011.

[8] H. W. Lee, K. S. Kim, J. H. Seo, and Y. S. Kim, "Effectiveness of a perforated light shelf for energy saving," Energy and Buildings, vol. 144, pp. 144-151, 2017.

[9] G. M. Jeon, H. W. Lee, J. H. Seo, and Y. S. Kim, "Performance evaluation of light shelf based on light environment and air conditioner environment," KIEAE Journal, vol. 16, no. 5, pp. 47-55, 2016.

[10] G. A. Warrier and B. Raphael, "Performance evaluation of light shelves," Energy and Buildings, vol. 140, pp. 19-27, 2017.

[11] H. Lee, G. Jeon, J. Seo, and Y. Kim, "Daylighting performance improvement of a light shelf using diffused reflection," Indoor and Built Environment, vol. 26, no. 5, pp. 717-726, 2017.

[12] H. Lee, S. Kim, J. Seo, and Y. Kim, "Study on movable light shelf system with location-awareness technology for lighting energy saving," Indoor and Built Environment, vol. 26, no. 6, pp. 796-812, 2017.

[13] M. H. Moazzeni and Z. Ghiabaklou, "Investigating the influence of light shelf geometry parameters on daylight performance and visual comfort, a case study of educational space in Tehran, Iran," Buildings, vol. 6, no. 3, p. 26, 2016.

[14] A. Meresi, "Evaluating daylight performance of light shelves combined with external blinds in south-facing classrooms in Athens, Greece," Energy and Buildings, vol. 116, pp. 190-205, 2016.

[15] Y. W. Lim and C. Y. S. Heng, "Dynamic internal light shelf for tropical daylighting in high-rise office buildings," Building and Environment, vol. 106, pp. 155-166, 2016.

[16] Y. W. Lim and M. H. Ahmad, "The effects of direct sunlight on light shelf performance under tropical sky," Indoor and Built Environment, vol. 24, no. 6, pp. 788-802, 2015.

[17] P. Xue, C. M. Mak, and H. D. Cheung, "New static lightshelf system design of clerestory windows for Hong Kong," Building and Environment, vol. 72, pp. 368-376, 2014.

[18] A. A. Freewan, "Maximizing the lightshelf performance by interaction between lightshelf geometries and a curved ceiling," Energy Conversion and Management, vol. 51, no. 8, pp. 1600-1604, 2010.

[19] A. A. Freewan, L. Shao, and S. Riffat, "Optimizing performance of the lightshelf by modifying ceiling geometry in highly luminous climates," Solar Energy, vol. 82, no. 4, pp. 343-353, 2008.

[20] S. T. Claros and A. Soler, "Indoor daylight climate-influence of light shelf and model reflectance on light shelf performance in Madrid for hours with unit sunshine fraction," Building and Environment, vol. 37, no. 6, pp. 587-598, 2002.

[21] L. O. Beltran, E. S. Lee, and S. E. Selkowitz, "Advanced optical daylighting systems: light shelves and light pipes," Journal of the Illuminating Engineering Society, vol. 26, no. 2, pp. 91-106, 1997.

[22] R. M. N. Saraiji and R. G. Mistrick, "The development of coefficients of utilization for light shelves," Journal of the Illuminating Engineering Society, vol. 22, no. 1, pp. 139-162, 1993.

[23] Illuminating Engineering Society, The Lighting Handbook, Illuminating Engineering Society (IES), New York, NY, USA, 10th edition, 2011.

[24] JISZ 9110, Recommended Levels of Illumination, Japanese Industrial Standards Committee, Tokyo, Japan, 2010.

[25] KSA 3011-2013, Recommended Levels of Illumination, The Korean Standards Association (KSA), Seoul, Republic of Korea, 1998.

[26] K. Kim, H. Shim, H. Lee, J. Seo, and Y. Kim, "Development of rolling type light shelf with adjustable reflectivity," KIEAE Journal, vol. 16, no. 5, pp. 57-64, 2016.

[27] Y. S. Cho, B. S. Kim, and J. S. Lee, "Analysis on the indoor daylight performance and optimum size selection of a light shelf using lightscape," Journal of the Architectural Institute of Korea Planning \& Design, vol. 20, no. 6, pp. 231-238, 2004.

[28] D. Y. Heo, H. W. Lee, and Y. S. Kim, "A study on performance evaluation of lighting performance of internal light shelf according to the reflectivity," Information, vol. 18, no. 5, pp. 2117-2122, 2015.

[29] H. Y. Ahn, H. W. Lee, and Y. S. Kim, "A study on light shelf system based on it in housing space," KIEAE Journal, vol. 13, no. 1, pp. 133-140, 2013.

[30] S. Oh, H. Lee, Y. Kim, and J. Seo, "Research on lighting performance evaluation for different curvature reflection rate in residential space," Korean Journal of Air-Conditioning and Refrigeration Engineering, vol. 27, no. 6, pp. 328-336, 2015. 


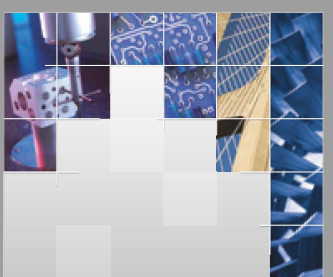

\section{Enfincering}
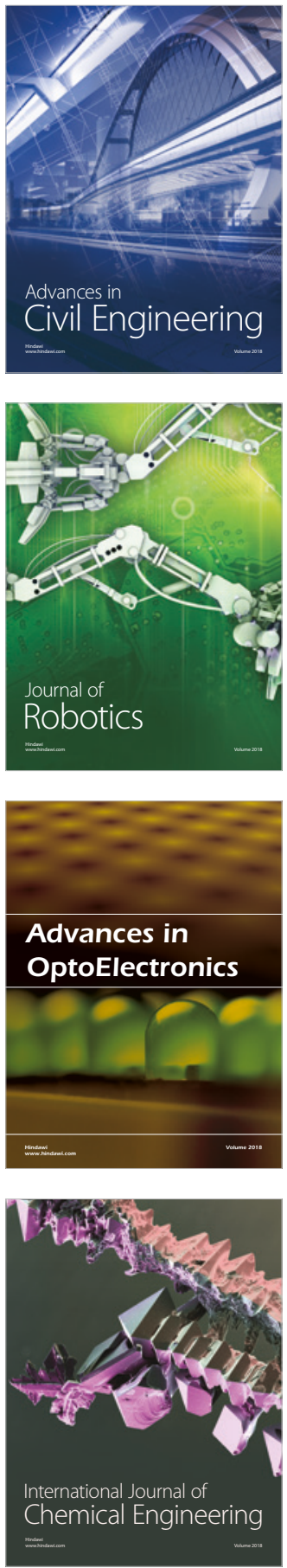

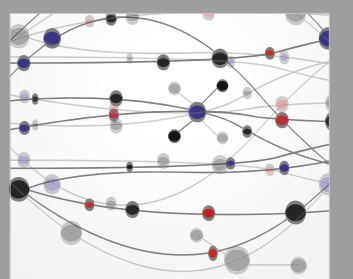

\section{Rotating \\ Machinery}

The Scientific World Journal

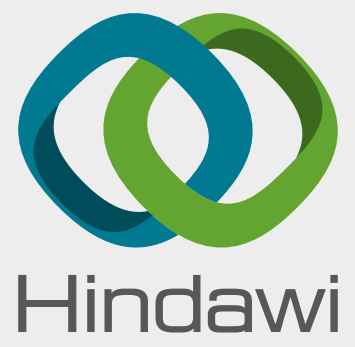

Submit your manuscripts at

www.hindawi.com
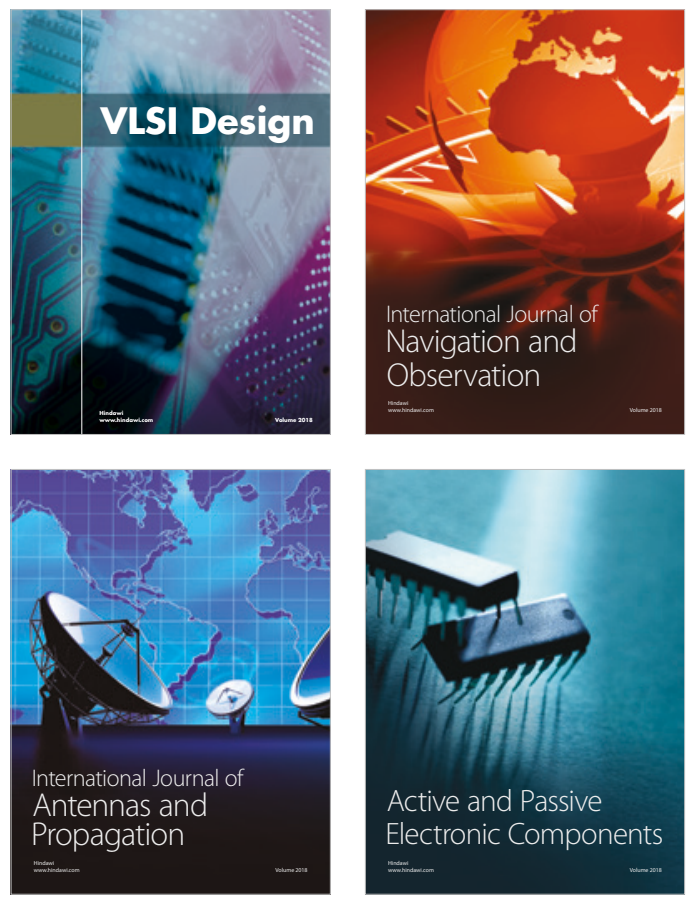
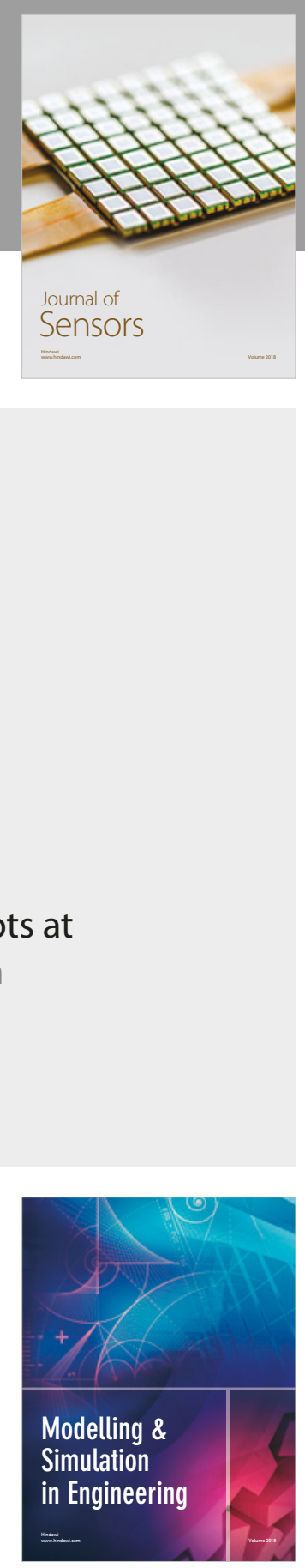

\section{Advances \\ Multimedia}
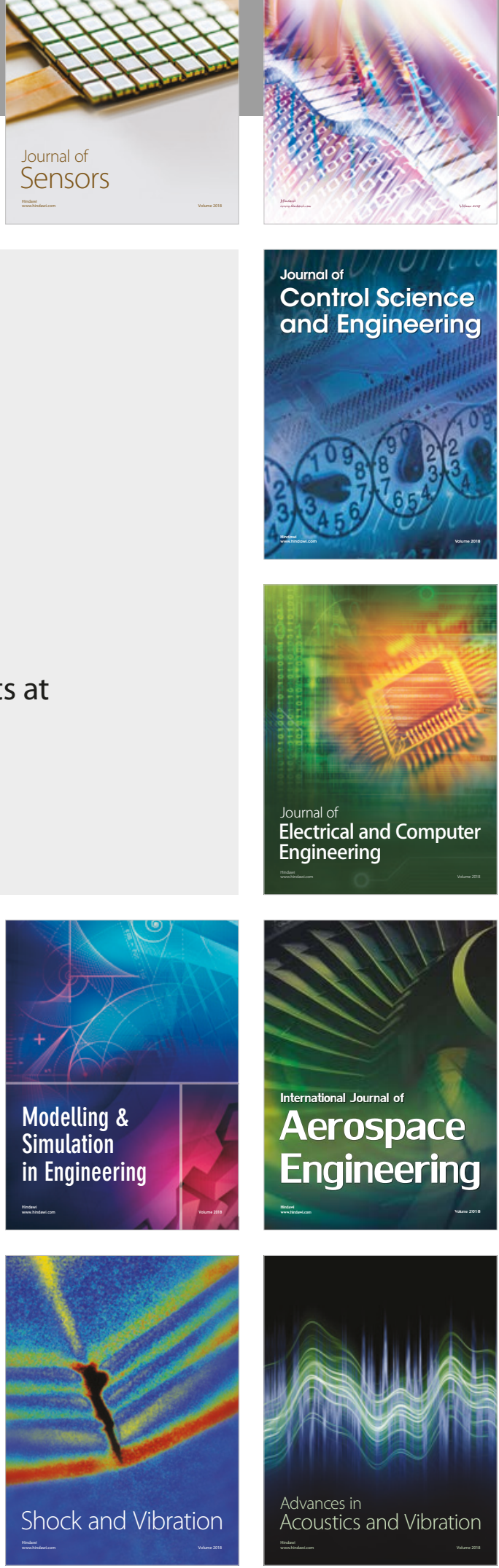